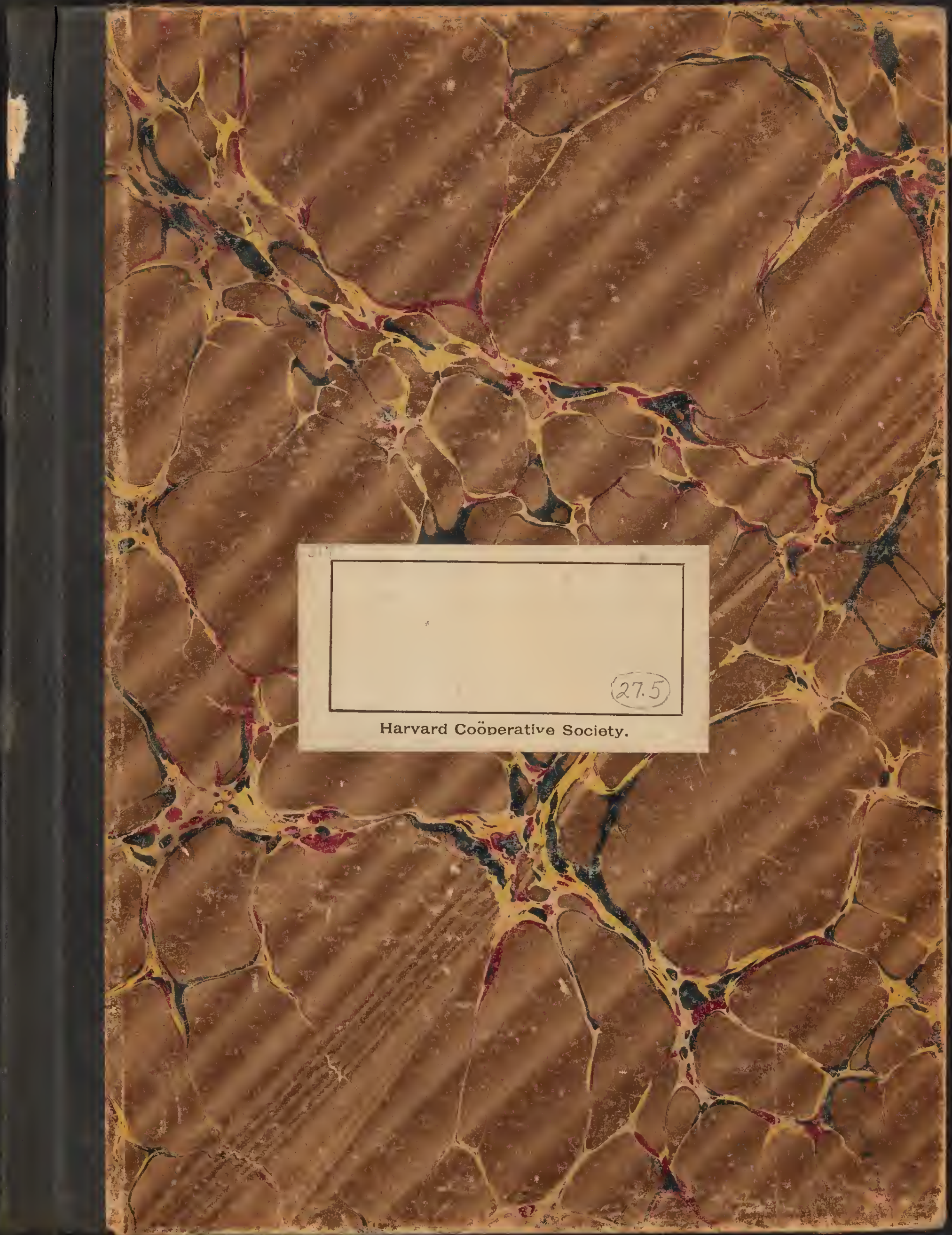


ANNOTATION LABEL

BOTANICAL MUSEUM OF HARVARO UNIVERSITY

notes of Drs. B.L. Rosinson T. M. Greenman

on Lewis + Clark's plan 'sc Miss Day's

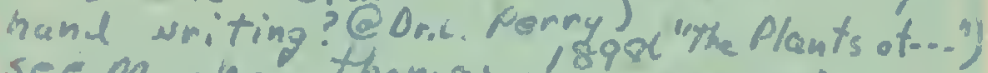

sec Mechan, thomas philu. i $898.12-49$

Robert Bye

I C E P . 1971 
rewn+ 


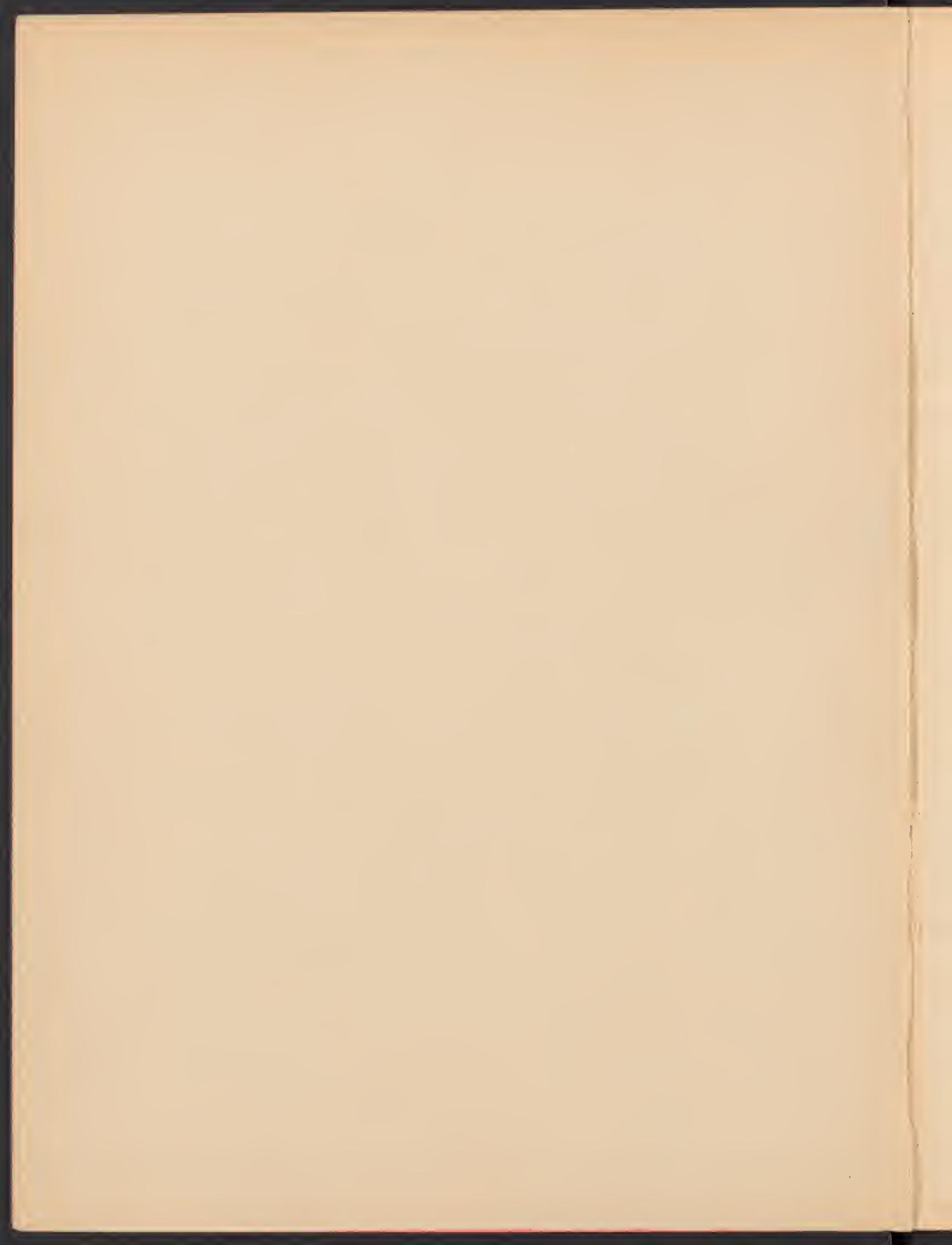




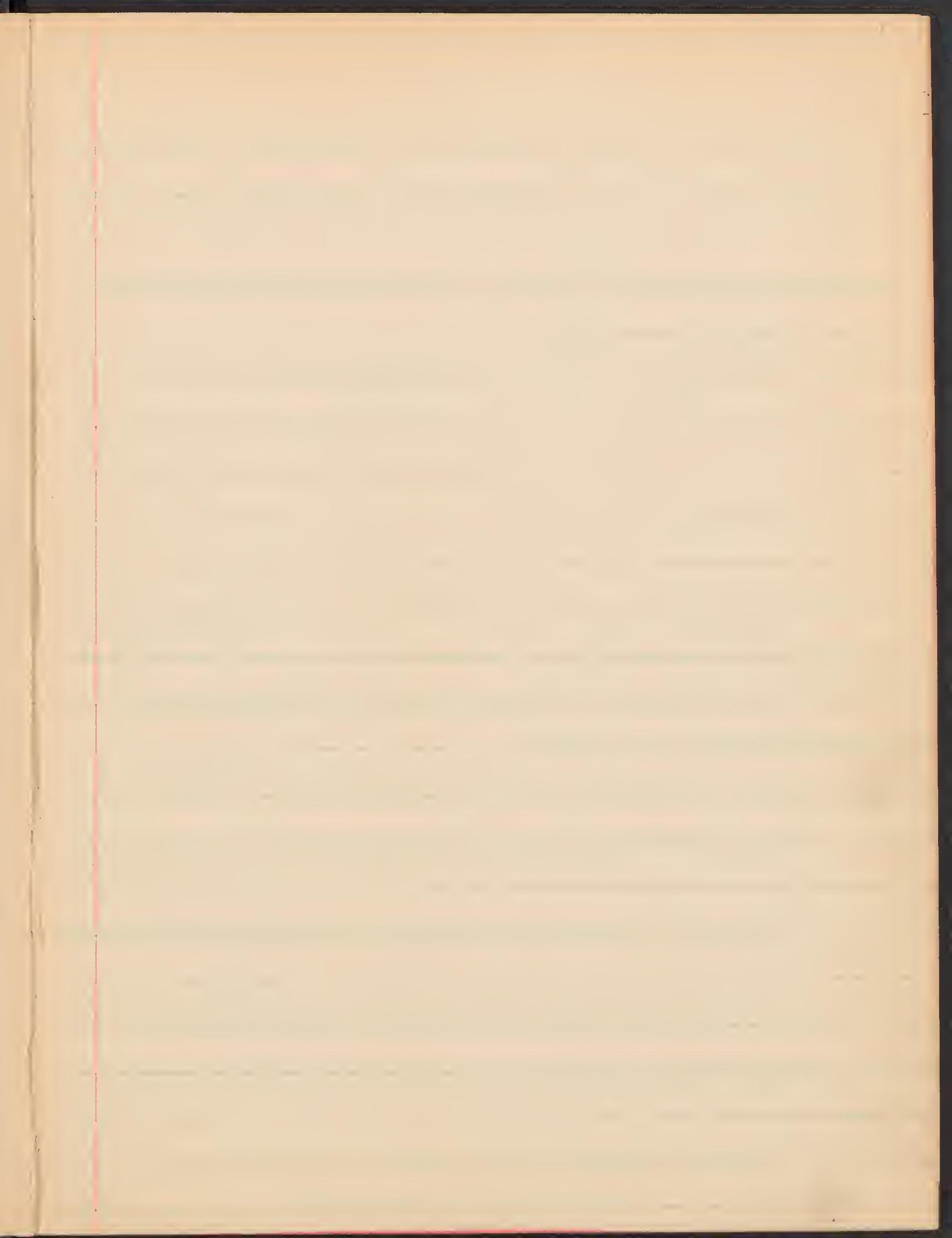




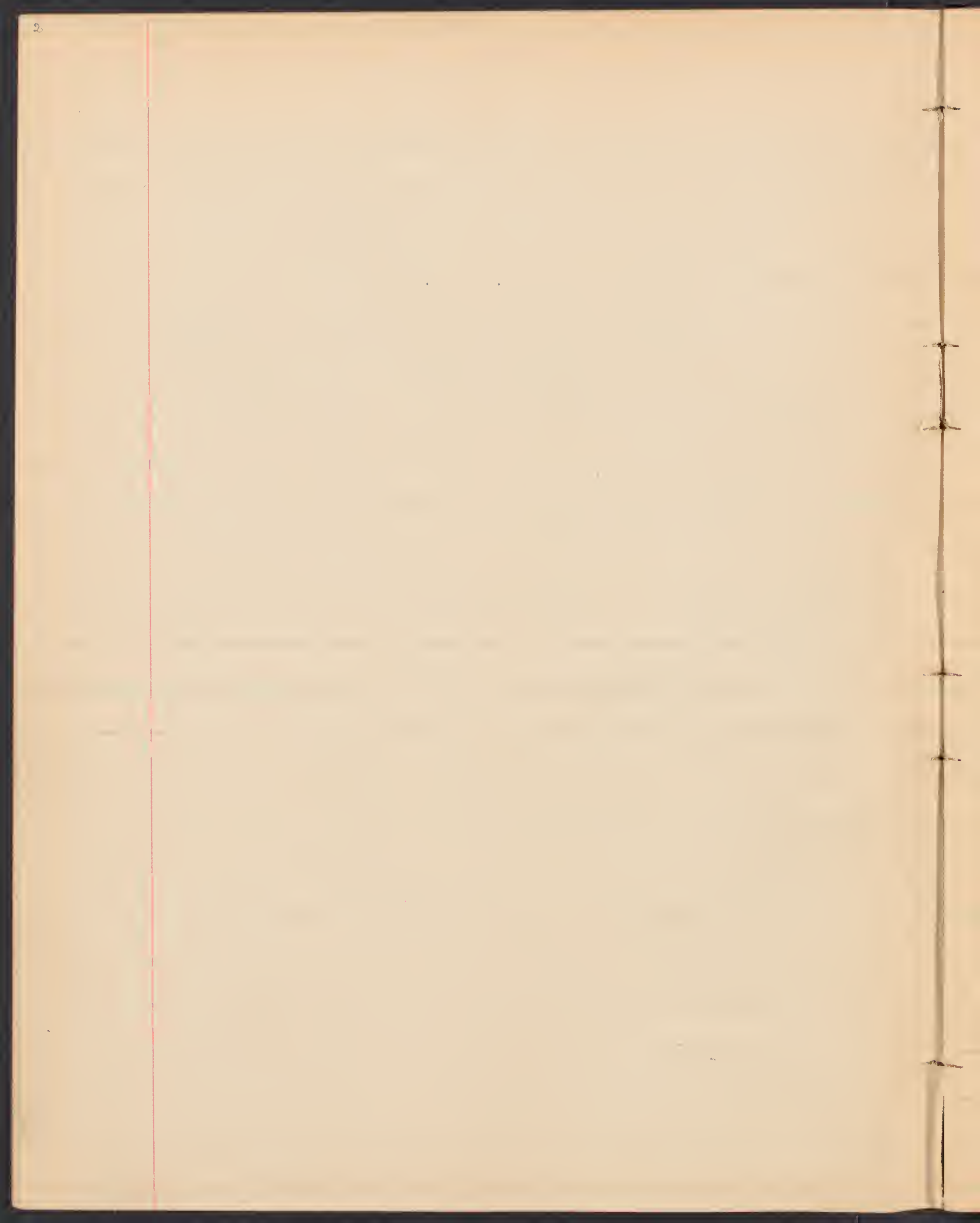


Tresent incme of plant, focloured by data on accompanying labels.

Treatinent of flant in Pursh's Jtora whenever specfiéally mentioned.

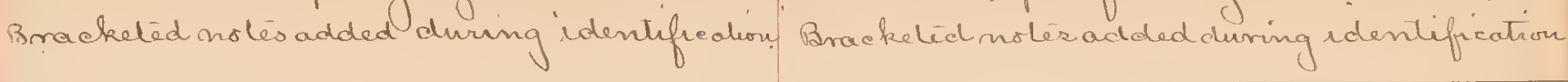

Anem one Canadensis, $\mathcal{L}$.

(a.Pennsylvanica, L.) Prairus; in the camp near the old Maha orllage- ang. 17. 1804.

Anemone quinquefolia, $\mathcal{L}$. Qn itre vaters of the Jhoos kooskce, June 15, 1806. LAlowvering stein vitu involuce.]

Glematis Douglasii, gbook. I nolabel, a single flower Put well iderifiable.

Delphinimu Menziesic, DE. Onthe Columbia, April 14.1806. A rort of Larkspur wint 3 styles. [Poor apecimen:-

Eurth searcely a doubt $b$. hirsutuosima, Pursh, Il. 385 , being the only specier aseribed to Leuris' Herbarum.] Gn the plaine of the Golumbiariver 24. May. v.s. in Berl Leuris. 
4

Dentariatenclla, Pursh.

Pursh, Tl. 439. Qn the tanks Bolumbia near Sricksands of the Columbia. 4. Apr. v. S. April 1,1806. EComplete very in Jerb. Leurss.

slender plant.]

Erysinmm aspermm, De. Elanceolatim, Pursh, Jl. 436. Qn the Kooskooskee, fune 1.1806. (not R. Br.) Cn the banks [Whole plant, in flower.] of the missouri. F. June. U.S.

Eleome integrifolia, Jorr. Isay. Co.pcrrulatā, Pursh, Il. 441. Elcome serrulatà, var roseus, lentre banks of the hovaspecies. Specimenfrom Missouri. $\odot$. Ang. v. s. Whité River, August 29.1806. in Berb. Leurs.

Bleome. A new spceies. LLaves are shighity serrulate. [Poor specimen.] and mame should stand.] 
5

B.integrifolia, Jorr. Eray. no.43. Anguat 25. grourt of the open Praries. Epen farairies aug. 25, 1804
B. serrulatá, Pursh, Jl. 441. Cn the banks of the Missouri. $\odot$. Ang. v.s. in Oberb. Leuis.

E Pursh sayz of it glabra which is certainly true of the slem and it may therefore besafely separaled from the very pubescent-falant Polanisia trachysperma, J.9. S. (?) with which trespecimen is mifed.]

Golongatum, Purah, Jl. 32\%. Curtre plains of bolumbia River. m. Levis. 24. April. v.s. in gerb. Leuis.

Thabastrim coccineum, Inay Gristariacocinea, Pursh, Amahraceous small plant Fl.453. Unotry frairiés and probably a species of Malope, extensive felains of missouri. Plains of missouri guly 20, 2. Ang, v. v.; v. s, in Dberb. 1806. [Sood specimen.] Leuris. 
6

Limun Leursie, Pursh: Pursh, Il. 210 Im the Perennial flax. Valleys of valleys of the Rocky: mownthe Rocky mountains, July tain and on the banks of 9,1806. EEfcellent ppecimen. the Missouri. 'M. Leurs. 4. July. v. v.

Glaytonia lanceolata, Pursh. Pursh, Fl. 175, t. 3. Un Headwaters of the Clooskoos the Rocky-mountain. kee, ginne $27,1806$. [Sood specimen.] m.Lenis. 24. July. v.s. in gert. Lewis.

Levisiatriphilla, Rob.

Qnithe vaters of the Joos -

kooskee within the Rocky

mountains. Gune 2\%. 1806.

(tay Toniatriphylla, Wats.)

[Eqtinds range to Idaho.] 
Leursia rediviva, Pursh. The Indians eat the root of this. Near blark's R. July 1, 1806. The ealy, consiats of 6 or T leaves the corolla mony petals and stainens many …. capsule. [Several flowers only.]

Montia parirflora, Obouvell, form. Qn itre Golumbia, in moistground, march 26, 1806. [ A very poor and indefinitéspecimen.]

Montiafeariflora, Howell. Rocky camp. apar. 17.1806. [Sood specimen]

Montia sibirica, Bouell. bolumbia R. Apr. 8.1806[Fair Apecimen]
Pursh, Fl. 368. Cn the tanks of elarckssuiver. 2. guly. U.S. in Tberb. Luvis. 
Pachystimamyrimites, Raf. Rocky mountains gume 16.1806

Pachystima myrsinites, Baf. with a small deep purple berry. evergreen. Near the Pacifie lecan. Mor.16, 1805. [second specimen.]

Geanoithus velutinus, Dougl. An evergreen, Ashrub about 8 or 9 f. high. Unitre Rocky mountainis. Waters of the Tooskocakce. [Probably not the B. sanginnens, Pursh, altrough that-species collected by Lewis does not appear in collection.]
Tlex? myrsintes, Pursh, Jl 114 Qncthe Rocky-mountains and near the Pacific Ocean.

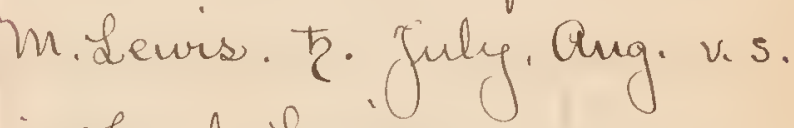
in rberb. Leurs.

Pursh, Jl. l.c. 
Rhamnus Purshinana, DG. A shrub apparentty a speciee of Rhanmus. About-12 feet high in Clumps. fruil a 5-valved purple berry which the natwes eat and esteem highly. The berry depresse d globous. On the waters of the Ktoos kooskee. may 29, 1806.

Rhus banadensis, var trilobatá, Esray.

no.57. Uct. 1, 1804. first descovered in the neighbourhoord of the

Kanorg river - nour very common. the grouth of the little copseswhich appear on the steep declinties of the hills where they are shellerech from the ravages of fire. Bommon on the dectivity of hills. (lect. 1 . 1804
R. alvifolnus, Pursh (not michy.) Fl.166. Cn the banks of the Kooskoosky, m. Leuis, th may. v. S. in oferb. Lewis. 
Gissus Ampelofair, Pars. near Counsel Bluffs, missouri, Sept: 14.1806. [Leaves, flem, peduncles and pedicels. - Levis,' specimen not mentioned by Push, who gives range of species as Allegheny is., Pennsylvania. to Carolina.]

Acercircinatum, Push.

Avery handsome species of maple. (ln the great rapids of Columbia. Oct. 1805. [Sterile but highly characteristic and unmistakable.]
Push, Fl. 26\%. Con the great rapids of bolumbiariver.

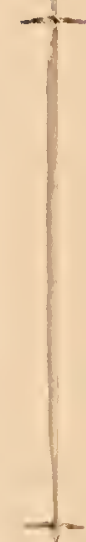

$-$

Acermacrophyllum, Push. Push, Fl. 267. En the great Alarge timber lie e from the rapids of the Columbia river grand rapids of the Columbia. M. Lewis. $\hbar$. Apr. vi. apr .10.1806. [a single leaf butruabily recognizable.] 
Polygala alba, nutt.

Polygala seneca, var. temifolia A kind of Seneca snake-root: Pursh, Il.750. Qn the misouri, Cnitre MissouriR. Oug. 10.1806. Leuis and Bradbury. v. S. Fairly completé epecimen.] Amorphafriticosa, var, $r$ Pursh, Fl. 466 , vary. V.S. in angustifolia, Pursh. Cntre Herb. Levis. great bend of the missouri, ang.27. 1806. [Lood specimen in fruit:]

istragalus missouriensis, mutt. no.36. $18^{\text {th }}$ sept: the grouth of the high Praries.

Astragalus mortoni, hutt. no. 46. The grouith of the open praries taken is $\frac{\text { th }}{\text { of }}$ Sept: 1804. Astragalus- nov spec. Open prairies, Sefet. 5.1804. May be a. nualensis? L. 
12

* Lupinus argentēus, Pursh. Pursh, Il. 468. Qn the fanks Wu the Bokahlaishkit, july 7. of the Kooskoosky. M. Levis. 4. 1806. Flowersyellowish-white. June, Guly. v. s. in Jberb Lambert. [Tood speciearion] tlowers small creana-colored.

* Lupenus sericeus, Pursh. Purah, Fl. 468. Wn the banks hew species. Flowere creamerlorid of the Kooskoosky. m.Lemis. I. with a emall tinge of flue. Guly. v.s.in Xerb. Lewis. Un the Clooskooskee, Gune 5,1806, Flowers faurfele, or rose-coloured. [ Jolerable specimen.]

* Thelabels of these turo apecimens were confused.

Qujtropis mana, hutt. var. Rear the head of Clarkis River.
0. Argentala, Pursh, Il. 473. On the banks of Glareks river. Guly, 1806. EDiffers from ligke M.Leavis. 24. Guly. v. S. in Xberb. in having calyttrect longer; Leirs. alsoplant-larger, leaflets longer.]

Petälosténou violaceus, michx. Pursh, Til. H61. In Jennessee, On the Missouri July 22.1806. Lllinois, and ou the banks of [Stem, leaves, thapike of flowers.] the misaouri. 2t. July-Sepl. v.v. 


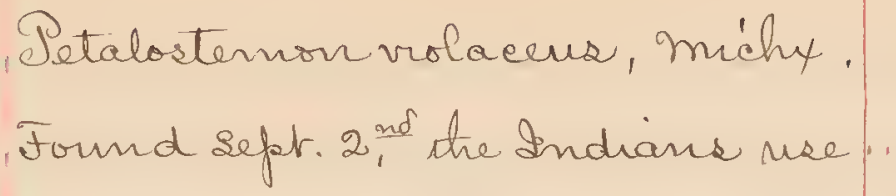

Purdah. Fl.l.e.

13

it as an application to fresh

rounds, they bruise the leaves

adding a little water and apply

it. I sterile specimen only and accordingly doubtful.]

Psoralea argophylla, Push.

Push, Fl. 475 . Cu the banks. no.48. no.103. Get. 17. 1804. a decoction of the plant-nsed by the Indians to wash the ir wounds. [Steril abut characteristic specimen.]

Psoralea tenmiflora, Purse. of the missouri. Ht. vas.

Big bend of missouri. Sept. 21, of the missouri. 'm. Levis. 2. 1804. [Stein and leaves.] sept. v. s. in Herb. Lewis.

Trifolium megacephalum, nut. Lupinastèrmacrocephahe, Push, A species of clover near Rockford Il. 479, T.23, At the head waters Camp on high hills. Apr. 17. 1806. of the Missouri. M. Levis. I. ISpecinen consists of a head on April, May. U.S. in Kerb. Levis.

$v$. peduncle and several detached leaver.] 
Trifolium microcephalum, Pursh. Pursh, Tl. 478. Cn the banks Valley of Glarkis R. July1, 1806. LEood specimen, corresponds. of Blarck's river. M.Leuris. 24. July. v.s. in gherb. Levis. well with later plants placed inspecien.]

Amdanchier alnifolia, hutt. Pifrus sanguinea, Pursh, Fl.340, Service berry. A small bush, in part. In banada and on the narrous of Bolumbia River. the banks of the Bolumbia. apr. 15.1806.

5. Apr. may. v. v.

Brataiegus Douglasii, Lindl. Deep purple Baw. Columbia R. apr. 29. 1806.

C.glandulosus, Pursh, Fl. 337 , in fart, notwilld. m.Lewis. T Esof. collected it on the Rocky mountanis.

Seum triflorum, Pursh. Qn open ground coumon on the waters of the KooskoosBeum chliatum, Pursh, Fl, 352. Qn the tanks of the Kooskoosky. 2. Jume, V.S. in Fberb. Leuirs. kee, gune 12.1806. no.2.

Sirus sambueifolio, cham. Schlecht?

Qnitre tops of the highest-peaks mountains

June 27.1806. In tho Rocky inurntaius. Sppecimen

ver poor, terile mot precisely determinable.] 
Potentilla anserina, L.

The roots are eal - by the matives \&.

taste like sweet potatoes, grows in marshy ground, Fort Clatsop, march 13,1806 .

Potentillafiriticosa, L.

Prairy of the throbs, guly 5.1806.

Pursh, Fil. 355. Un the banks of [Small but characteriotic ppecimen]. of the Rocky-mountains, gune-Aug. Levis. v. vinghortis, v.s, in oberb. Lewis.

Prunus demissa, hut.

Prumus, a cherry found near the beaver bents on the misouri Ang.10.1806. Especimen poor and sterile.]

Prumus Virginiana, Lo.

Prumus. Bhoak or Pridgeon cherryQn the waters of the Kooskoosky. 29 may, 1806. [Specimen poor and sterile.] 
Poumus? Rear itrebase of the Rocky mount on the urest side near bollins's creek. The phrub about 6 or 7 feet high, gune 2\%, 1806.

[inrecognizable.]

Srunus? Ashrub about 6 feet high from the Jooskooskee, may 7.1806. Linrecognizable, dark purple plèn, elliptic perrulate leaves.

Prunus sp. a smaller shrub than the choakberry, ithe matures count it a good fruit. Un the Kooskooskee. 29, may, 1806. L Joo yoor for identifi cation.]

Puralia tridentata, De. Ashrub eommon to the ofen ferairic of the Knobs, july 6, 1806. [Sood apecimen.]

Jigarea tridentala, Pursh. Il. $333, t .15$. In the praries of the Rocky-mountains and on the Columbiariver. $\%$. July. v. s. in derb. Levis. 
Rosa Woodsii, Lndl.

no.30. Cect. 18. The amall rose

of the praries - itrises from 121014 Inches high-does not vine. RosaOpen ferairies, Seft.5.1804.

Rubus Mutkana, var velutina,

Brew. A shrub of which stren matives eat - the young sperout writurent kooking. Cn the bolumbia. Apr. 15, 1806.

Rubusspectabilis, Pursh.

Purah, Fl. 348, t.16. Con itu banks, Truit like a rasberry, Bolumbia of the bolumbia, m.Lewis. An march 27. 1806. [a fairly good apecimen shouing plèm, leaves and flowers.]

the mont weat crast, menzies. ?. apor. may. v.s in Herb. Lewis, nee nou banks.

Spiraca descolor, Purah.

Pursh, Flora, 342. Cen the A shrub growing much in the Vanks of the Kooskoosky. $\frac{1}{\text {. }}$ manner of hine bark. Un the June, July. v. S, in Jberb. Lewis. waters of the YKooskooskee, may $29,1806$. 
Philadelfhus Levisu, Pursh? Pursh, Fl. 329 .

Ashrub from the Keorkoosky.

may 6,1806. An Philadelfohus?

Lsterile and too poor for certain

identification.]

Philadelphus Leursu, Pursh. Pursh, Il. 329. Cn the waters Qn the waters of Blark's R. of Blarck's river. T. July. guly 4, 1806. Lovirly good. v.s. in Rerb. Leurs. flowering ppecimen.]

Ribesaureum, Pursh.

yellow flowering Currant: hear the marrous of the Columbia R.
Ribescureum, Pursh.

Yellow eurrant of tre missouri fuly 29.1805. L The sting futfrom date not itre Type.]

Ribes Mengieari, Pursh,? Tl.732.

Deep furple Gooseberry. Colum. L Pursh does not mention Lewis' bia R. Apr.8.1806.

Pursh, Fl. 164 the rivers missouri and bolumbice. m. Leuris. T. Apor. v.s. in gherb. Leuris, v.v. in Goort. 
Ribes sanguineum, Pursh. Columbia, march 2\%.1806.

Ribeaviscosissinnm, Bursh. Errit-indifferent and gummy. The hights of the Rocky mountains novits uneriea. Im. Lewis. t. Jime 16, 1806 .

Blarkia fulchella. Pursh.

abeantiful herbaceons plantfrom the Kooskooskee o blark's R. June 1.1806. [Fair specimen.]

Oinothera cáspitosa, mutt. near the falls of the missouri. falle of the
17 guly, 1806 . [Eood specimen.] guly, U.S.

Q. cácapítosa, Pursh, Fl. T35. Cn the Vanks of the missouri. M. Lewis. 24. Jume, guly. V.S, specimen imperfectim in Derb. Leuis. 
20

Conothera heterantra, mut. In moist ground ow the squarish flats. give 14.1806. LSoodspecimen:

Sedum Rtenopetalum, Push. Push, Fl. 324. Un rocks on Valley of elarkis River. July 1, the tanks of Clark's river 1806. Un the Naked rocks on and Tooskoosky. T4. June, the Kooskooskee, June 5, 1806. mountain in moist paces. Time 25, 1806. The flowering one taken in Sepal. $3^{\text {rf }}, 1805$. [Label only.]

Probably a Pencedanum, poor specimen, no fruit: ] Alarge fusiform root which the natives prepare by baking. hear the Sepulchre Rock. On the Columbia River. April 14. 1806. 
Percedanum livearpum, Nixtt. Smyrnium andréaule, Pursh, supposed li be a Smyrnium. Fl.196. An the Colmmbiariver. In. The natives eat the tops and boil Lewis. 24. apr. may. v. s. in rberb. it sometimes with their soup. Levis. The natives eat itre tops Qn the Columbia. April 15.1806. of tris plant-and boil it in their Roups, thesame as we docelery. Eirroneously flaced under Jerula and Peucedanum mudicaule, hutt]

Pencedanum simplex, nutt. (or P.triternatum, Pursh.) Aroot 5 or 6 inches long eaten raw or forled by the natives. (ln the Kooskooskee. May 6. 1806.

LLeaves only and species very doubiful. P.triternatum is said to grow on the waters of the bohmbia.] 
P

Pencedanum utriculatum,

Shellandrium aquationm. Pursh

Mutt? Agreat-horse medieine among the matives. (en the Jooskooskee. June 10,1806. grows on rich upland. Ispecimen poor and not certaincly identifiable.] (not-2.) Fl.195. Un the waters of itre Rocky-mountain. m. Lewis. 2. July. v.s. in Tberb. Levis. The Indians of that eruntiny use it ar a medicine in the diseases of horses.

An unbelliferous plant of the root of which itre Wallowallows make a kind of fread. The matives called it-shappalell. Apr.29.1806. Fsterile and not placed-leaves and root.]

\section{[Label only.]}

Arpecies of fonncl root eaten by the Indians, of an annisseed Caste. Flowers whité.

Colmmbia River, Apr.25.1806. 
Lmidentifiable.]

An umbelliferous plant with large fusiform root which the natives bake and eat. En the Gohmbia. apr. 15.1806.

[unidentifiable, slems only.] An mmbelliferons plant of which the natives doniteat the root. Qrrstrebolumbia. Apr.14.1806.

Cormus Canadensis, $L$. Roothorizontal gune 16, 1806. Bollins Breek.

Lonicera ciliosa, Poir. Qn the Kooskooskee, June 5, 1806. Caprifolimmeiliosum, Pursh, Fl.160. Cen the banks of the Kooskoosky-M.Lewis. $\hbar$. Jume, v.s. in gerb. Lewis.

Lomeera ciliosa, Poir.

Rockymonntain, Jume 16, 1806. [Poor and plérile but charactersotic.] Baprifolium ailiosum Pursh. l.e. [but not-type apo cimen.] 
Lonièra involueratá, Banks. Shrub witwin the Rocky moun-' tans found in moist ground near branches of rirulets, July 7.1806. no.5. found on the waters of tre bolumbia, Septi 2. 1805, the grourth of a moist situation seldom rises higher than 6 or 8 feet- fauts up a number of suceculent- sprouls forming a trick bush. [stenes only.]

Achillea millefolium, \&. bappon the Kooskooskee, mary. 20.1806.

Aplopappus pfemulosus, DG. Prairies Sefet.15.1804. a. Tomentosa, Purah (not Willd.) Fl. 563 . Cn the tanke of the Kooskoosky. 'm. Leuris. 24. June. v.s. in Herb. Levis.

Anellua spinulosus, Pursh, Il. 564. In open farairies on the missouri. 'm. Leviss. If. Ang. Sept. V.S. in Oberb. Lewis. 
Aplopappus sp.

Cn tre Columbia, Let. 1805.

Artémusia cana, Pursh.

no.55. Let.2.1804. growitu of the high Berffs.

Arteminsia cana, Pursh. Qnitre bluffs. Oct. 2, 1804.

Artenisia cana, Pursh. Qn the bluffs. Cet. 1. 1804 .

no.60, 1804, Cocr. 1. Another variely of wild sage growith of high and bottom prairies

Artémisia elracunculoides, Pursel

Q. Dracunculus, Pursh (mot: \&.) no.52. Sept.15, 1804, growith of the Fl.521. Cn the missouri. openfalains. En the bluffs. Sept: M. Lewiss. 4. Ang.-Udt. v. S. 15.1804. [Eoodspecimen] in Rerb. Lewis.
Pursh. Fl. 521. Cnctre missouri, In. Lewris. 4. Sept-nou. U. S. in Gerb. Leuris.

Pursh, Jl. l.e.

Pursh, Fl. l.e. 
26

Artemusia frigida, Willd. Purah, Fl. 521 . Cn the plains no.41. found on the bluffs the of the Missouri. M. Levis. 2 nd of Sept. 1804. is the grourth 4. Oct. Nov. V.S. in Herb.Lewis. of open high situations. On the bluffs. Sefet.2.1804.

[lood specimen]

Artemusia frigida, Willd. Pursh, Tl.l.c.

ho. 51 . 1804, lect. 3, radix peremial. 3 to 8 stalks as high as the speeinen - growith of the high sides of the Bluffs.

Artenusia longifolia, hutt. A integrifolia, Pursh (not-Willd.) Wild sage on the bluffs. Qct. Fl. 520. Entre cliffs and dry 1.1804. No.53. Qct.3. Hawor saramahs of the misouri. likestre camomile-radix M. Lewis. 4. Qct. V.s. in Jeerb. perennial grouth of then Leuis. about three feet high. Thigh Bluffs.

Artermsia Ludoviciana, hutt? Artemisia species. Bolumbia R. Apr.10,1806. Arternisia. Rockford Camp. 
27

Aster oflongifolins, nutt. Big bend of the missouri, sept. $21,1804$.

Roter Qreganus, Nutt. Qn Lewis River. Uetober, 1805.

Balsamorrhiga sagittata, nutt, Buphthalmumpagittatim, Pursh Rocky mountains - Dry hills. Fl.564. Lndry Farren hills in finly T. 1806. the Rocky mountains. In. Leivis. 4. June, july. v.s. in Gerb. Leurs. Thenatives eal the young sterns as trey apring up, raws.

1e.)

Balsamorrhiza pagittata, nutt. Buphtralmum pagittatum, The stim is ealen Gy the natives Pursh, l.e. uintoutany preparation. Custre bolumbia, April 14, 1806.

L Bídens-like composile, too poor to identify. I Cn Levis River. Col. 1805. 
28

Bigeloura graveolens, Estray. Alow shrub growing in the rocky dry hills on the Jos kooskee. 'may 6, 1806 .

Bigeloura graveolens, Gray, bhrysocomadracunculoides, ho.54. Q et. 2. grows from 18 Push (not Lam.) Fl.517. (ln Inches to 2/2 feet many stalks high cliffs on the banks of the from the same root, from which Missouri. M. Levis. I, Met. they josue near the ground -the vas. in Herb. Lewis. radix perennial. The goator antelope feed on it in the winter, it is the grout of the high bluffs. Sigh Bluffs; goats feed upon. 18 inches. high, Q et. 2, 1804 .

Bigeloura grave dens, var. Ghrysocoma nanseosa, Pall. albicaulis, Gray. in herb. Push, Jl.517. Cl 15 let. 1805, on the Columbia the banks of the missouri. river. m. Lewis. 24. Oct iv. v. in Hers. Lenis. 
20

Omieus edulis, Sray.

Bardurs - or Thistel - Rooto

eatable- Fort Clatsop. March

13,1806

Eriophyllum cáepaitosum, Dougl. Aetinclla lanata, Pursh, Fl. Cn the aplands on the Koos - 560. Cn high lands of the Joos. kooskee R. Gune 6.1806. koosky. M.Lewis. 2. June, july, v.s. in dberb. Leuis.

Taillardia aristata, Pursh. Pursh, Fl. 573 . Cndry hills on Rocky mountains. Dry the Rocky-mountains, M. Leurs. hille. July 7, 1806. T. v.s. in Herb. Leurs.

Srindelia squarrora, Dunal. Donia Rquarrosa, Pursh, Il. 55\%. no.40. Taken on the 17 th of august, In open frairies on the banke 1804. at our camp near the old of the missouri. 'M. Leurs. 21. maha village is is the grourth of the Ang. Sept: V.S. in Dberb. Levis; Praries. Anonymus falsamiferan V.U. cull-

new genus. Prairies; in the camp near the old Maha village, Ang. 17. 1804. [Lood specimen.] 
Putierrezia Euthamiae, Jorr. Eray. No. 32. Specimens of aromatio flants on which the Antelope feeds - These were oftaines 21 st of Sefat. 1805, at the upper part of the big bend of the Missouri. Mpper part of tre big bend of the Missouri, Sept. $21,1804$.

Intrerrezia Euthamiae, Torr. O Sray. no. 59. 1804, $19^{\text {th }}$ Seftemberthegrourth of high and bearpraries which paroduce liute grass, generally mineval earth. High bear prairice mineral earth with very litite grass. Seft. 19.1804.

Liatris,pyenostachya, michx. No.35. Septi.15. growith of the praries. Prairies Seft. 15.1804.
Solidago Sarothrae, Pursh, Fl. 540. An the flains of the miscouri, m. Lewis. It. Sept. v.s. in Kerb. Lewis. Solidago Sarothrae, Pursh, Il.l.c. 
Liatris seariosa, Willd.

no. $53.12^{\text {th }}$ September, grouth of high and dry praries. Obigh and dry prairies Sept. 12, 1804.

'Matricaria discoides, $D e$. Anagreable smell. En the Tooskooske, gune 9, 1806.
LLevis speeriner not mentioned by Pursh.]

Santolina saveolens, Pursh, Fl. 520. Un the banks of the Kooskoosky. 'm. Leuvis. O. June,-ang. v.v.' v.s. in rberb. Leurs.

theroceris macrochâete, Eray. Rock Camp. April 17.1806.

Solidagorigida, L.

Obigh dry frairied. Septi 13, 1804.

LComposilé? Poor, Rterile and not-placed-leaves of posite, much divided inlo narrow segments, very pubescent.] Gre of themost common plants of the plains of bolumbia, may 27.1806 . 
Aretostaphylos Wva-ursi, Spreng: Arbutirs Mva-ursi, Pursh (not no.33. An evergreen plant which Willd.) Fl. 283. On the plains grous in the open plains usually. of the Mississifpi the Indians the natives smoke ilo leaves smoke the leaves under the mame. mited unithtobacco called by the of Sacacomis, and consider Thench Engagee (?) Sacacommis, them of great medianal oftained at Fort-mandon. Fort virtine.

Mandor - open plains - Evergreen called Sacacommis, natives smoke its leaves.

Mrbutis mengiesiu, Pursh. Amiddle sized tree with a remarkable smooth bark which scales off in the manner of the Pirch; Hred berries, in clusters. Columbia R. hov.1.1805.

Laultheria Shallon, Pursh. The Shallon; supposed to be a species of Vaceinium - (ln the coast of the Pacific Qcean. June 20.1806.

Pursh, Fl. 282. Lbut does notmention Leuris'specinen.]
Pursh, Tl. 283. En the falls of Golumbia and mear the weetern Qcean. In. Lewis. 5. May. June. v. s. in Pberb. Leuis nec non Banks. 
33

Vacionium mystellus, L.

new species - With a purple pmall

berry eatable - an evergreen. Fort

Elatsof - june 20.1806.

Vaccinium ovatum, Pursh.

Pursh, Jl. 290. An then A shrub of For 8 feet-high, sup- Columbia river. m. Leurs. posed to be a species of Vacinium $\hbar$. May.

the berriee are eaten by the natives.

Qn the Pacific Qcean-Fort Glatoop.

june, $27 \cdot 1806$.

Dodecatheon Ineadea, L.

near the narrours of the Golum-

bia R. aper. $16,1806$.

Irasera thyrsiflora, Hook. Swertia fastigiata, Pursh, Fl. In moist wet-jelaces- In 101. Un the missouriflats, the squamash flats. Jume 14, near the Rocky-mountains. 1806. [Leaf only.] M. Levis. 24. July, v.s. in fbert. Lewis.

Gollomia linearis, nutt.

Rockford bamp. apr.17.1806. 
34

Gantria aggregalà

Siliaaggregata, spreng.

Pursh, Il. 147 . Cn the tanks of

Qn hungry creak, gume 26.1806. The Mississippi. ' $m$. Leuris. [Flowering stem.]

8'. June v. S. in Gberb. Learis.

Potemonium eãeruleum, L.

Head waters of the Hooskoosky.

June 27.1806.

Phacelia circinata, jacq.

Thacelia heterophylla, Pirsh, Il.

Root fibrous, plant-from 3-4

140. Un dry hills on the banks.

feet-high; dry intuation, An the of the Kooskoosky. M. Leuris.

Kooskooskee. Jime 9.1806.

[Pror specimen.]

$0^{\pi}$. Jume, fuly. v.s. in gberb. Lenis.

Phacelia menzieaie, Torr! H y drophyllum hneare, Pursh, Rocky camp. Apr. 17. 1806. Fl. 134. On the banks of the missouri. M. Leuris. 4. aparil. v.s. in Oberb. Leurs. [Specimen in Herb. Philad. Acad. shouring flowers and leaves, root annual, not peremnial. ] 
Plagiobotrrys tenellus, Eray. Rocky camp. Apr: 17.1806.

Trynitakia sp.?

Rocky camp. Apr.17. 1806.

Nicotiana quadrivalves, Purh
no.45. Specimen of the Ricara's

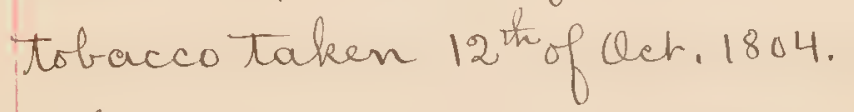
12 of Oct. at ithe Ricara's lown. This is the tobaceo which they enltivate.

Collinsia farifflora, Dougl. Rockford Camp. Aparil 1\%, 1806. From size of corolla apparenety b. parvifloraracter tran b. violacea asplaced by Eray. yetidentety is not-certain.] 
Thmulus huters, $\mathcal{L}$. Un the waters of Plark's River. july 4, 1806. [Indifferent specimens fut shourng stem, leaves \& flowers - upper pertion of the plant is not glabrous as described by Pursh, l.e. But finely and densely glandular-puberulent.] Crthocarpus tenuifolus, Benth. Valley of Glark's R. July 1, 1806. [agood specimen, shouring the root to be distencily annual, not perennial as described. The color of the flower is not shown.]

Pedicularis Eroenlandica, Retz. En the low plains on tre heartiof Blark's R. July 6.1806.

Pinncinata, Willd. Dursh named this Puncinata, Willd. (Siberian) on his label, but-evidenty discovered his error before publication as in his 'thora he gives P. Eröenlandica.]
Bursh, Fl.426. On tretanks of Blarck's river. $M$. Leuris. On the norte west coast, Pallas. 4. July, Ang. V.s. in Herl. Lewis nec non Lambert.

Barteiatenmifolia, Pursh, Il. 429. Cnthe banker of Elarck's river. 'M. Lewis. 24. July, v. S. in Kert. Levis.

Purah, Fl. 426. In low plains of the bolumbio. M. Leuris. 4. July. V.S. in Herb. Lewis nee non Lambert. 
Pedicularissacofulorum, Eray? Qn the low flains on the heout of Clark's River. Guly 6. 1806.

Pentstemon diffusus, Dougl. Camp on the Kooskoosky. may 20. 1806.
Pielata, Pursh (not-willd.) Jl. 425. In the low flains, on the waters of Elarck's river. 'M. \& ewis. 4. july. v.s. in Herb Levir. IPelata, Purah, not Willd. has beren doubtfully referred to P. Bracteosa, Bents. but it is certainly different. 2thas purple flowers as described, But the calyx is not glabrous fut pubescent. In all characters shown it agrees well with P. seopulorum, esray, noturihstanding difference in distribution and altitude.] 
Synitidys is remiformis, var. major, Jook. Un hungry creek. June 26.1806. [Does not well agree with Veronica reniformis, Pursh (Ex char.) Il. 10, forthat-is said to have a ereeping stem, opposite leaves and alterrnaté peduncles, and to have been collected in boggy soil on the tanks of the missouri.]

Salvia lanceolatā, Willd. Big bend of missouri, Sept.21. 1804. [Good specimen.]

Scutellaria arigustifolia, Puroh. Un the Hooskooskee, June 5, 1806.

Cxybaphremy ctaginensis, Sweel. Cpen plains. Sept: 1. 1804.

[Fairly complete.]
S. Trichostemmoides, Pirsh, If 19. In open plains of the missouri niver. 'M. Leurs, O. v.S. in Gherb. Lewis.

Parsh, Il. H12. Un the river. Kooskoosky. m. Leuris. H. June. vis. in gberb. Leivis.

Allionia ovala, Pursh, Il.97. Cn tre plains of the Missouri, $m$. Leuris. O. Aug. V.S. in Herb. Lewis. 
Atriflex canescens, james. Sept. 21, Biglend of the Missouri. Sept.21.1804.

Atriplex nuttallii, vats. A half shrub from the high plains of missouri, fuly 20.1806.

Sarcobatus, maculatus, Jorr. A small branchy shrub from the plains of missouri, July 20.1806.

Polygonum Pistortioides, Pursh. Polygonum, near to Birtorte. In moist grounds on quamash flate, fine 12, 1806. LLeaves and inflorescence.] 20.1806.

balligonimn eanescens, Pursh, Fl. 370. In the plains of the Missouri, near the Big bend.

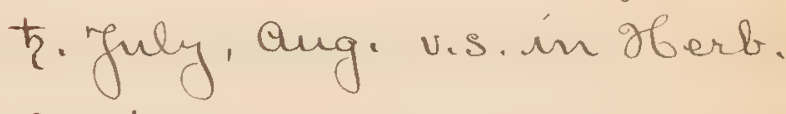
Leuris. 
Éleagnus argentéa, Jursh. Silver tree of the Mnisoouri, Jrem the proinire of ithe strobss. fiely 6, 1806 .

Shepherdia argentea, 'nutt. t. no.39, Ht oftained at the mouts ofthe river Qmicourre from which place upevards it is abundant, in she missouri bottoms it is apleasant turig tó eat, it has much the flavor of the cranbury and continues on the bush through the virnter- this izan evergreen shrut. some plantś are sent down by the barge to the care of bapt Stoddard at St. Lonis. From the mouts of the piver Qmic ourre sf from there repuardos in all the missouri botloms. The berry pleas ant acid like cramberry thang on all wintèr. Evergreen.
Dursh, Fl. 114 . In the extensive plains ou the qanke of the Misaouri. In. Lewis rand J.H wtall 5. July. U.S. in Bherb. Lewis. misoouri silver tree.

Suppophaie argention, Pursh Fl.115. Entrefanks of the missouri. M. Lewis. t. v. S. in Oberl. Lewis. 
41

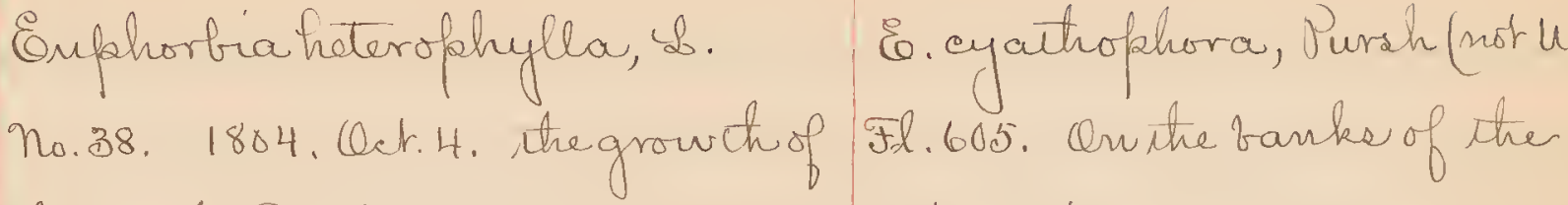
the Pigh Praries or plains. Obigh Mississippi. \$. (.). June, July. prairies siplains. Cet.4.1804.

Euphorbia marginata, Pursh. Pursh, Fl.60\%. En the Gellow Cn the Yelloustorre River, fuly stone river. M. Seurs. O. July. $28,1806$.

Maclura aurantiaca, nutt.

[nolabel-sterile specimen.]

Betula?

Black alder of the Pacifie Qecan, grous to a large size. March 26 ,

1806. F Specimens consist-only of fragmentary sterile catkins.]

Qnerens Sarryana, Dongl. Q sort of while lak - Eshmbia. march 26,1806. 
Guercus macrocar pa, michx. no.34. The leaf of Oak which is common to tre Prairres. Is sepl: 1804. Common to the prairies. Seft. 5, 1804 .

Pofantusmonolifera, Rit. Pangulatā, Pursh (not willel) Bolton tree of the Misisissppi Il.619. Iris known by the name Gimissouri. Ang. 1806. of Misissippi Cotton Jree. [Levis' specimen not mentioned.]

Pokulustrichocarpa, Jorr. B. Eray. Golton tree of the Columbia River. Gune, 1806.

Galypzoborealis, Salist. Waters of hungry creek. Rocky mourtain. June 16, 1806.

Pursh, Il. 593. On the Golumbia river. In.Leuris. 4. may, fune. v.s. in berb. Levis:

Iris Missouriensis, hutt. [so far as fragmentary specinen shours.] A pale blue species of Flag. Prairie of the Itn obs. July 5, 1806.

Iris Sibirica, Pursh (not willd.) Il. 30. Qn the 'sanks of the Missouri. M.Leurs. 4. guly. v.v.; v.s.in oberb. Leuris? 
Alium sp.? Qn the vaters of: , the Kooskooskee. Qper. 30.1806. [Very poor pterile specinen.]

Brodiaca Donglasii, Wats. Obyacinth of the Colmmbia Flains. Apr. 20.1806. [Lood specinen]. [Watson's synon. wrong Proe am. M. Leuris. 24. Apr. May. v.v. Acad. XIV. 238, where Purshis grandiflorais jelacedrunder laeta.]

Galochortis elegans, Pursh. Asmall bulb of a pleasant flavour eat by the natives. An the Kooskooskee, may 17.1806. ISmall specimen - Ileaf and I flower. Specimen depauperate in manner of var. nanus, Word, fut patals oftusish and not ciliaté.]

[Perhaps a fart of] A. angulosum, Willd. of Pussh Fl. 223 . Qn the tankes of the Misouri. ' $m$. Leuris and nuttall. 4. July. v. s. in rberb. Leurs.

B.grandiflora, Pursh (not-Smith) Fl. 223. Cn the plains of the Columbia and missouri rivers. 
44

Camassia esculentā, Lind. Phalargirm Quamash. Push, near the foot of the Rocky mount- Ill .226. Un the upper part of the ain on the Quamash flats. June missouri, near the Rocky-mounitain 23.1806. [Good specimen.] M.Leuris. 24. June, V.S. in Herb. Lewis.

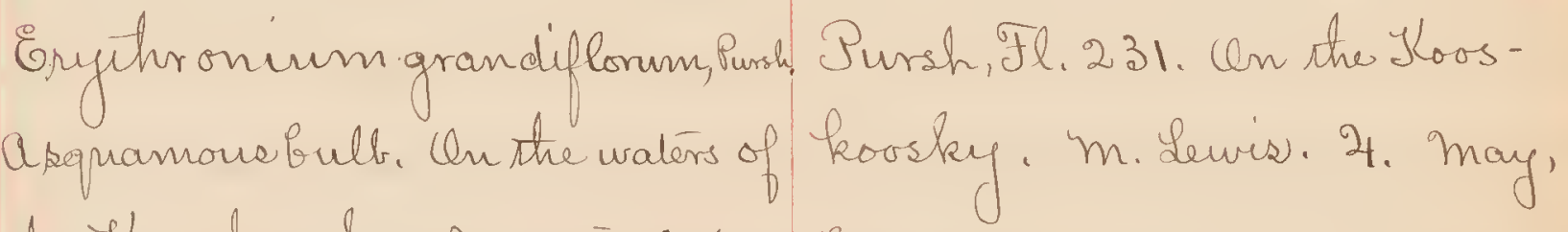
the Kooskooskee, gimme 5. 1806 . June, vas.

Finclifferent-specimen with one good flower and poor leaf.]

Eryetronium grandiflorum, var pariflorum, Wats.

From the plains of the Columbia

near Kooskooskce Riv. May 8, 1806.

The natives reckon the not

unfit -for food. [a flowers and

one leaf -bearing stem. Probably

the missouri specimen of $\varepsilon$.

lanceolatum, Push, Fl. 230.] 
45

Fritillaria lanceolata, Pursh. : Pursh, Fl. 230. Onithe head Specinen of eliliaceous felant waters of the missouri and obtained on Brant Island, $10^{\text {th }}$ Bolumbia. 'm. Leurs. 24. Inly. of Apar. 1806, the root of this plant V.S. is a squanus bult and is eatén by the natives. The Clak-clellar, ofposilèthis island, call il-Jel-lak-thil-pah.

LCompleté ppecimen.]

Fritillaria fudica, spreng. Liliunn? fudieum, Pursh, Fl. Plains of bolumbia near the 228, 5.8 . Curthe head-waters of Kooskooskee, May 8.1806. The the missouri. M. Leurs. 4. May. bulbin the shape of a bisquil v.s. in Ferb. Leurs. which the natives eat. . Gompleté Rpecimen corresponaing well with Pushis figure.]

Trithim ovatum, Pursh. Pursh, It. 245. On the rapids Golumbia River near the rapids of the Golumbia river. M. Lewis. aper. 10,1806. Eupper fortion 2. April. v.s. of falant: ] 
46

Trillium petrolatum, Push. Push, Fl. 244. An the waters folium. The flowers Grown if the Kooskoosky. M. Lewis. with a fruit of brick red. En 24. June. V.S. the waters of the Kooskooskee. June 15,1806. [Excelled t-specimen.]

Veratrum viride, Gil. or V. Galifornicum, Dur. Q plantgrowing in wet places with apingle flem \& leaves clasping round one another, no flowers observed. Un the Kooskooskee. june 25, 1806. [Single leaf only.]

Kerophylhm ten ax, nuts. Felonies tenay, Push, Il. The leaves are made use of by 243. On high lands near the natives to make baskets the Recky-mountains. and other ornaments. On high M. Lewis. 4. June, vi. land, Rocky mountains, June 15.1806. 
47

Zygadenus elegans, Pursh. Qn the Cokalaishkit-R. July T, the bokahlaishkit-river, near 1806.

Pursh, Fl. 241. Cnithe waters of the Rescky-mountains. 'm. Leuris. 2. July. U.S. in gberb. Lewis.

Purshy, Tl. 76 . In the plains of Oira Previfolia, Pursh. The most common grass through the nissouri, M. Lewis, 4. June, the plains of Bolumbia b near Guly. v.s. in Bberb. Leviss. This the Kooskooskee R. Gune 10,1806. grass is the most-common in Portrivialis, L. var. Fairspecmien. those plains.

Gordeurn jubation, L. Pursh, Fl.89. On the valands of Balled the golden or silken the missouri rivers. M.Leurs. A. Rye. An the white bear Yslands July. v.s. in berb. Leurs and Lambert. on the Mnssouri. Guly 12, 1806.

Gordaum fulsation, $L$ Pursh, Fl. l.e. Irass common to tre ofen grounds near Fort Blatsop. March 13,1806. 
Feshica ovina, L. var. Unstre plains of bolumbra. Gune 10.1806.

On the plains of the Golumbia. Gune 10, 1806.

Toeleria cristata, Pers. Qn the plains of the Bolumbia be. Gune 10.1806 .

Stipa spartea, Trin.

Valeys of the missouri on the Rocky-mountain Fuly 8. 1806.

Rigania aquatica, L. no. 59. $8^{\text {th }}$ Sept. the growith of moist and very wet praries.
Festrea duriusenla, Pursh, Fl. 83? [but Leuris' speeimen not mentioned.]

Festreca sprecatä, Pursh, Il. 83. Cn the waters of the misionsi and Bolumbicu rivers, gune. v.s. in Obert. Leuris.

Pursh, Fl. 85, Con the plains of the bolumbia river. In. Lewis 4. Guly. v. s. in Herb. Lewis.

Stipa juncea, Pursh (not:L.) FP. 72. Conche banles of the Missouri. m.Lenrs. 24. Ang. V.s. in Olerl. Lewis. 
29

LSterile ppecimen of a coarsegrass. nolabel.]

Pinms fonderosa, Dougl. Qn the Kooskooskee. Unriver Fottorns in rich land, west of the mourtains, Cel-1.1805.

LEeaves only.]

Juniperus communis, $\mathcal{L}$ No. 47. Appecies of gumper eommon to the Heifs. Cet. 17, Common to the Pluffs, Qect.17.1804.

$\mathcal{I}$.

Juniperus communis, L. var. Jumperus communis, L. var. alfina, Laud. Duarf deferesso, Pursh, Jl. 646 . Juniper-Rocky mountain [Leurs' specimen not mentioned.] July $7,1806$. 
Juniperus vecidentalis, Obook. ho.58. found 2 ${ }^{21}$ (Qct. 1804. A apcciea of bedar found on the Blufs the trees of which are large some of them 6 feet in the girts. On the bluffs. some trees 6 feet in girth Qet.2.1804.

jumperus Sabina, var. $\beta$ frocumbens, Pursh.

Dwarf cedar never moze than 6 inches high, open prairies lect 16.1804. [Small sterile epecimen.]

Equisetün arvense, L.

no. 31. groutt of tre pand bank near the banks of the river Taken the $10^{\text {th }}$ of ang. 1804 . sandbanks of the missouri Oug. 10.1804.
Juniperns epcelsa, Pursh (not Marshall von Bieb.) Jl. 647 . Qn the banks of the walers of the Rocky-mountaina. ' $m$. Levis. \$. May. v.s. in Herb. Leurs.

Pursh, Fl.647. Within the Rocky-mountaina. $m$. Lewis. F. V.S in Herb. Leurs. not above binches high. 
51

Aspidium spinulosum, Su.

Polypodium ppecies. Fort

Clatsop. June 20,1806.

Lomaria Spreant, Desv. Blechnumboreale, Pursh (not) Fort Clats of. Gune 20,1806. Willd.) Fl.669. Cen the morth west-coast. 'm. Lewis. 2t, ang. V.s. in Oberb. Lewris.

Tbypmim.

A species of moss from Fort clatsof. finne 20,1806.

A moss maed by the natives as a yellow dye grours on the Pines of the Rreky mountains. july 1.1806. 
Egregia Mengiesie (Jurn.) Aresch.

(Phyllos pora mengiesie.)

Fineus. From themouth of the Columbia River on the

Pacifie Qcean. Kor.17. 1805.

Loose label with Pirus

Sambuer olius? Gut datè different.] ho. 24. Lound the $4^{\text {th }}$ day of Sept. 1805. a amall grourt ouly rising to the hight-of 15 feet, moist situatuons it seems to prefer-it is a handsoner growith.

[Labelouly.]

The root not eaten by the natives Qn the bolumbia, april 14, 1806. 
EStérileand unidentified.

stem hgnescent, leaves opposite, narrow, linear, farcicled in axils. a shrub about if feet high. Con the plains of bolumbia, may 7.1806. 


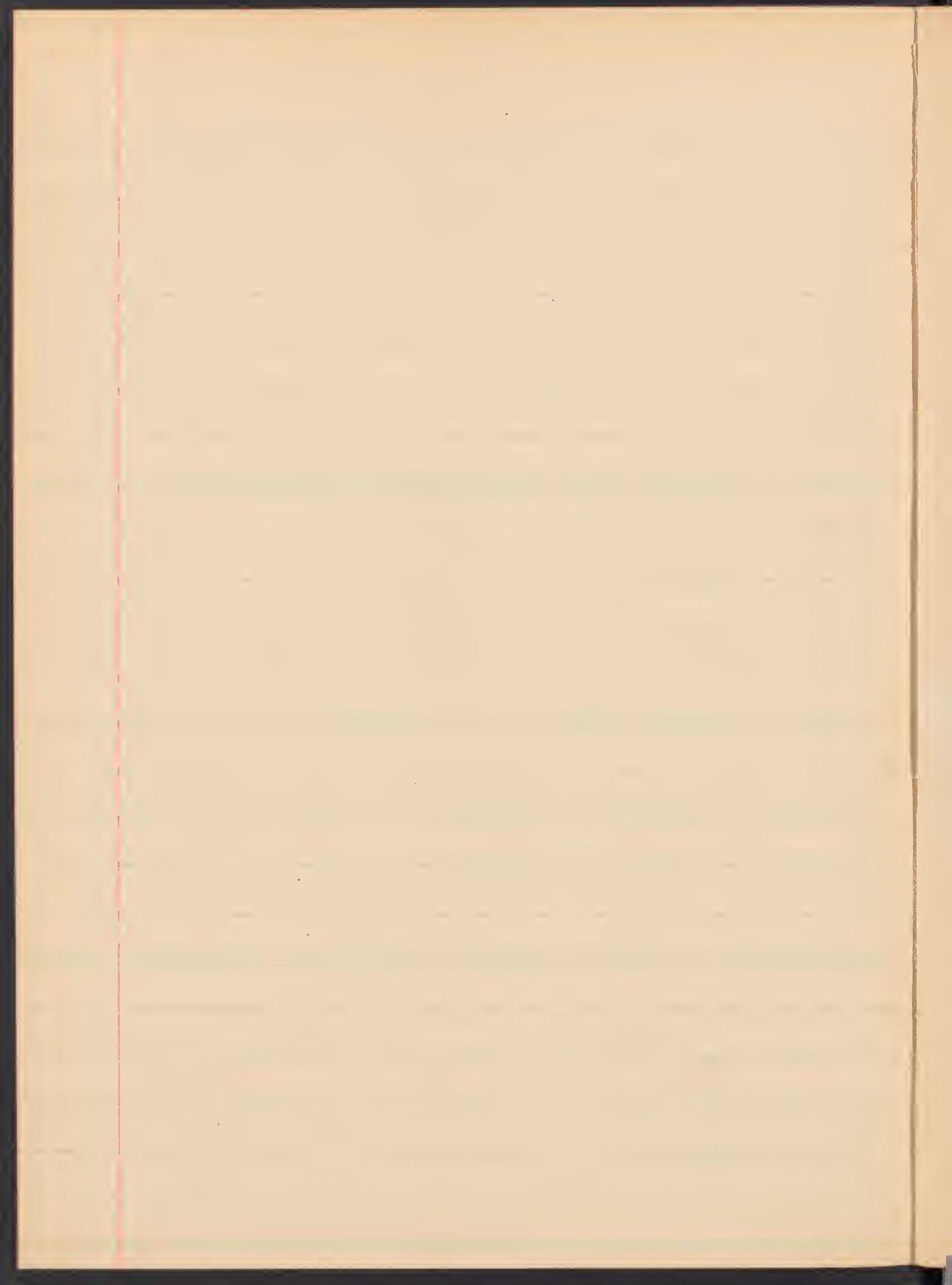




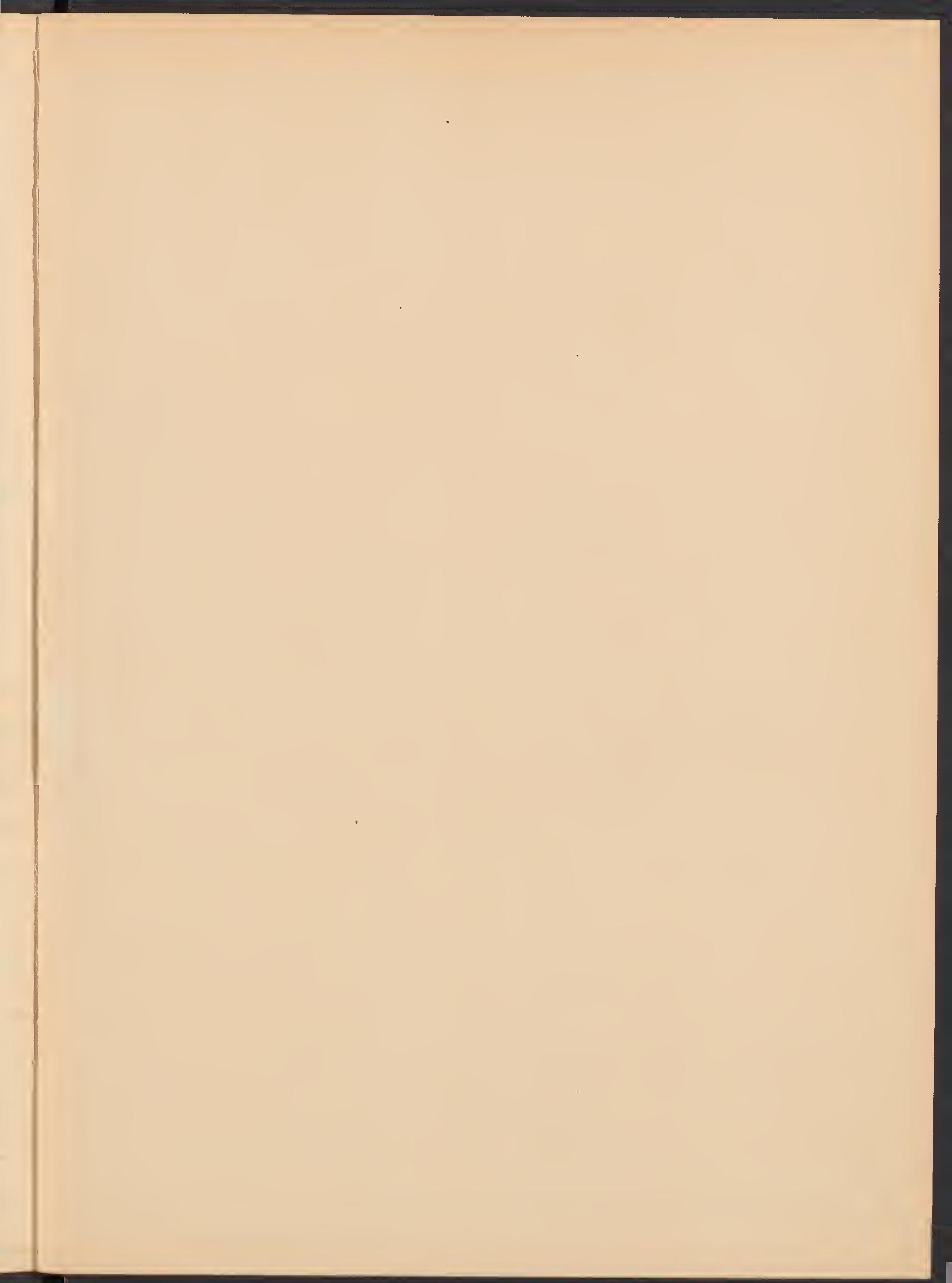




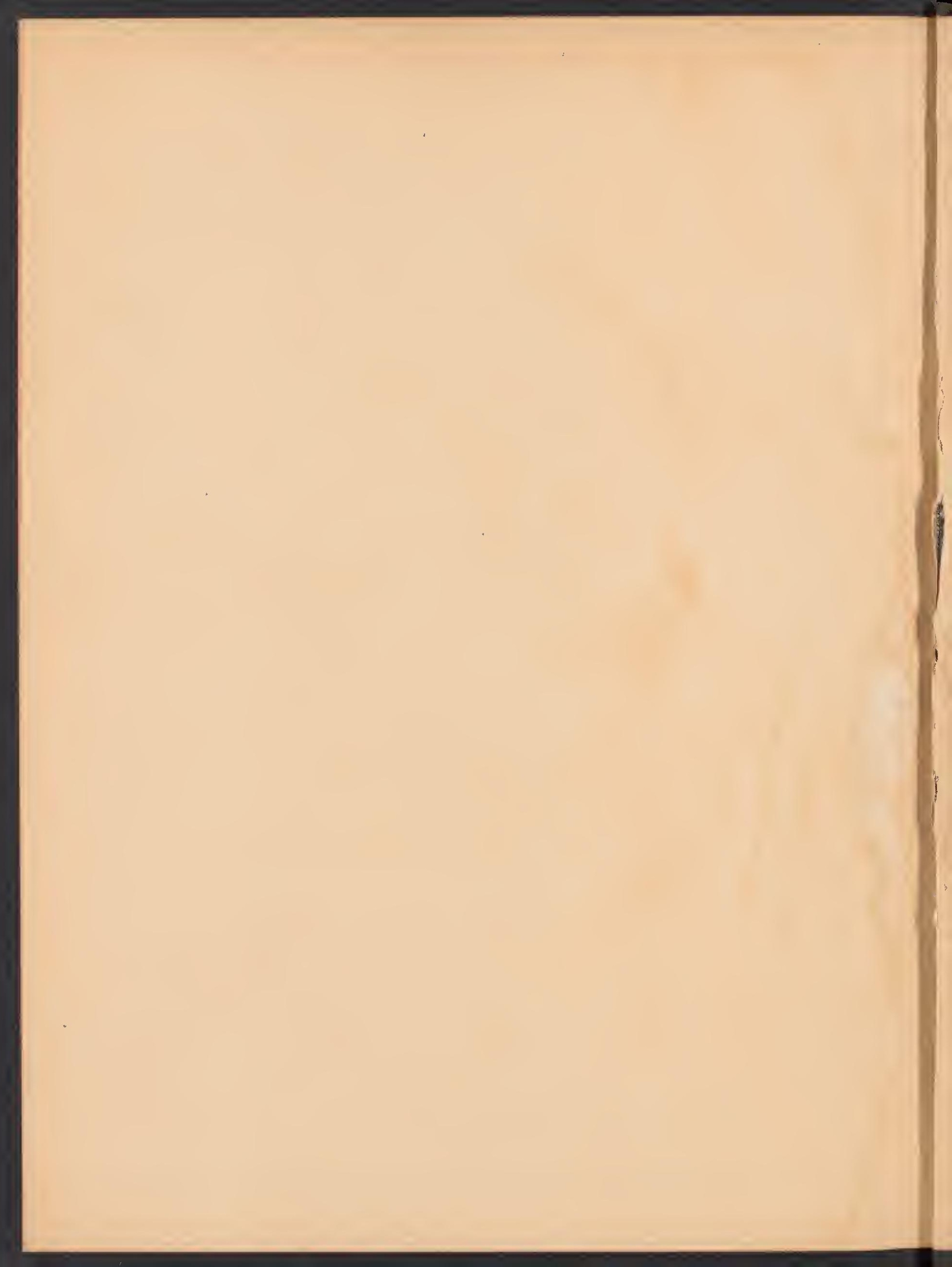




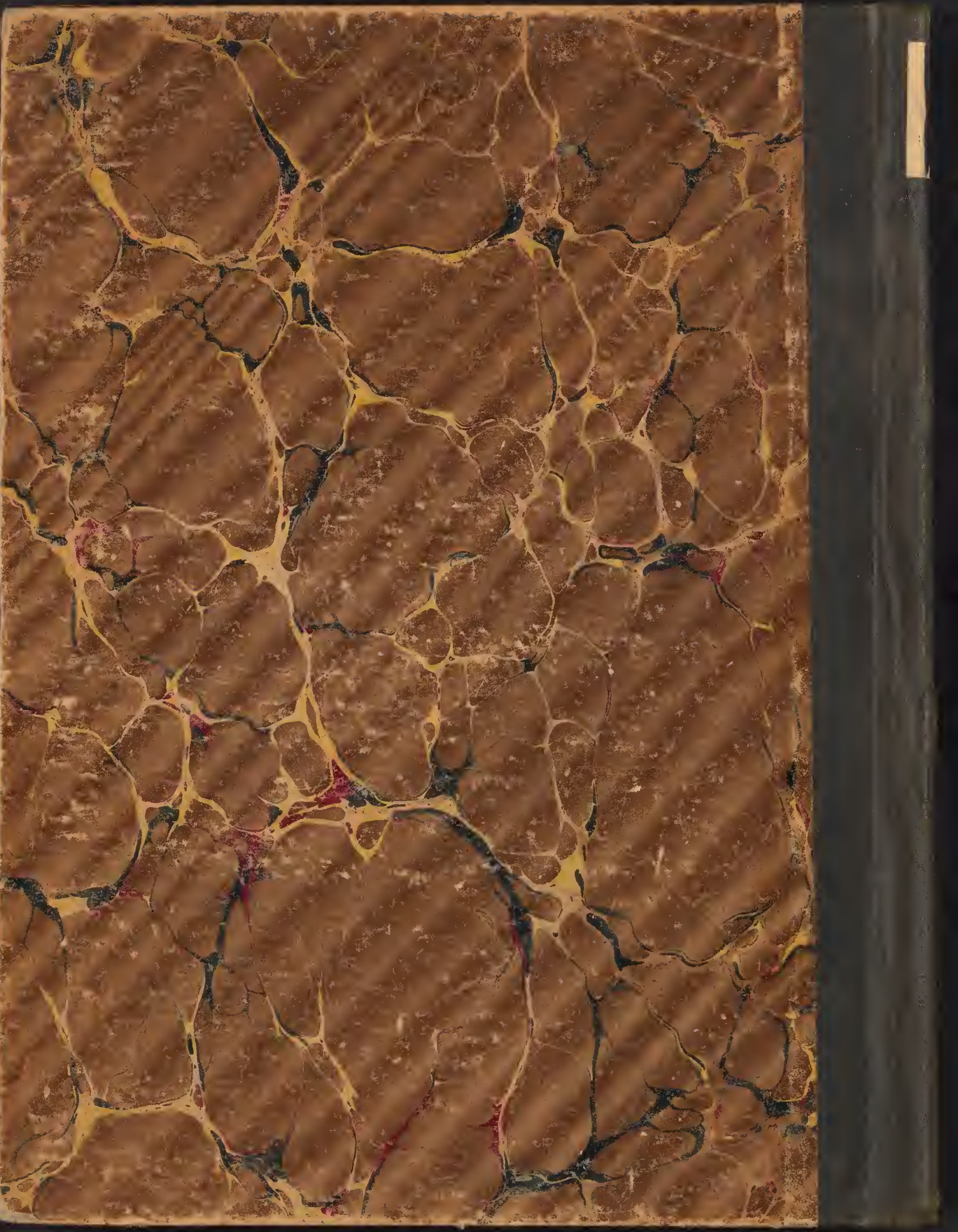

